\title{
ABCG2/BCRP gene expression is related to epithelial-mesenchymal transition inducer genes in a papillary thyroid carcinoma cell line (TPC-1)
}

\author{
E Mato ${ }^{1,2,{ }^{+}}$, C González ${ }^{1,3}$, A Moral $^{4}$, J I Pérez ${ }^{4}$, O Bell' ${ }^{1}$, E Lerma ${ }^{5}$ and A de Leiva ${ }^{1,3}$ \\ ${ }^{1}$ Thyroid Neoplasia Study Group, EDUAB-HSP, Biomedical Research Networking Center in Bioengineering, \\ Biomaterials and Nanomedicine (CIBER-BBN) ${ }^{2}$ Departament de Biologia Cel-lular, Immunologia i Neurociències, \\ Facultat de Medicina, Universitat de Barcelona, Spain \\ ${ }^{3}$ Departments of Endocrinology and Nutrition ${ }^{4}$ General Surgery and ${ }^{5}$ Pathology IIB, Hospital de la \\ Santa Creu i Sant Pau- Universitat Autònoma de Barcelona, Barcelona, Spain \\ ${ }^{\dagger} \mathrm{E}$ Mato is now at Sant Antoni Ma Claret, 167, 08025 Barcelona, Spain
}

Correspondence should be addressed to E Mato

Email

emato@santpau.cat

\begin{abstract}
Tumor malignancy is associated with the epithelial-mesenchymal transition (EMT) process and resistance to chemotherapy. However, little is known about the relationship between the EMT and the multidrug-resistance gene in thyroid tumor progression. We investigated whether the expression of the ABCG2/BCRP gene is associated with ZEB1 and other EMT inducer genes involved in tumor dedifferentiation. We established a subpopulation of cells that express the $A B C G 2 / B C R P$ gene derived from the thyroid papillary carcinoma cell line (TPC-1), the so-called TPC-1 MITO-resistant subline. The most relevant findings in these TPC-1 selected cells were a statistically significant upregulation of ZEB1 and TWIST1 (35- and 15-fold change respectively), no changes in the relative expression of vimentin and SNAIL1, and no expression of E-cadherin. The TPC-1 MITO-resistant subline displayed a faster migration and greater invasive ability than parental cells in correlation with a significant upregulation of the survivin ( $B I R C 5)$ gene (twofold change, $P<0.05$ ). The knockdown of ZEB1 promoted nuclear re-expression of E-cadherin, reduced expression of vimentin, $\mathrm{N}$-cadherin, and BIRC5 genes, and reduced cell migration $(P<0.05)$. Analysis of human thyroid carcinoma showed a slight overexpression of the $A B C G 2 / B C R P$ at stages I and II $(P<0.01)$, and a higher overexpression at stages III and IV $(P<0.01)$. SNAIL1, TWIST1, and ZEB1 genes showed higher expression at stages III and IV than at stages I and II. E- and $\mathrm{N}$-cadherin genes were upregulated at stages I and II of the disease (ninefold and tenfold change, respectively, $P<0.01$ ) but downregulated at stages III and IV (fourfold lower, $P<0.01)$. These results could be a promising starting point for further study of the role of the $A B C G 2 / B C R P$ gene in the progression of thyroid tumor.
\end{abstract}

Key Words

- $A B C G 2 / B C R P$ gene

- EMT inducer genes

- papillary thyroid carcinoma cell line (TPC-1) http://jme.endocrinology-journals.org DOI: 10.1530/JME-14-0051
๑) 2014 Society for Endocrinology Printed in Great Britain
Journal of Molecular

Endocrinology

(2014) 52, 289-300 


\section{Introduction}

Most patients with papillary or follicular thyroid tumors present survival rates close to $90 \% 10$ years after diagnosis (Hundahl et al. 1998). However, between $2 \%$ and $11 \%$ of these tumors develop aggressive behavior, with local recurrence or metastases at diagnosis or during followup, significantly reducing the survival rate (Cooper et al. 2009). The molecular mechanisms and the type of cells involved in the dedifferentiation processes in these tumors are complex and largely unknown. One group of cells that is known to be implicated in the development of these tumors and resistance to chemotherapy is cancer stem cells (CSCs; Mimeault \& Batra 2006, Dalerba et al. 2007, Akunuru et al. 2012). These cells possess stem-cell-like properties and share the expression of several stem cell markers (Li et al. 2013). However, their role in thyroid tumors is inconclusive (Lin 2011).

One stem cell marker detected in thyroid glands is the Prominin 1 (PROM1), also known as CD133. This marker, identified both in human cell lines and in biopsies from patients with thyroid cancer, contributes to radioresistance and maintenance of the undifferentiated status of the tumors (Friedman et al. 2009, Todaro et al. 2010, Ke et al. 2013). Another stem marker detected in thyroid cancer is nestin. Nestin is also known to be a marker of neuroepithelial stem or progenitor cells in the brain, and to be related to malignancy in some solid cancers (Krupkova et al. 2010). In the thyroid, nestin has been identified in differentiated thyroid tumors, but its expression does not relate to malignant characteristics of these tumors (Yamada et al. 2009).

In 2007, Hoshi et al. identified a cell population which expresses the $A B C G 2 / B C R P$ gene in the thyroid gland (Hoshi et al. 2007). This gene, referred to as the breast cancer resistance protein, is implicated in protection against several xenobiotics, in chemoresistance, and maintenance of the regenerative capacity of adult tissue. However, little it is known about its physiological role in the thyroid gland (Krishnamurthy \& Schuetz 2006, Robey et al. 2007, Thomas et al. 2008, Fatima et al. 2012).

Knowledge of the molecular mechanisms that control stem cell transformation into stem cell cancer is incomplete. Two of the most important mechanisms identified are the epithelial-mesenchymal transition (EMT) process and the mesenchymal-epithelial transition (MET) induction process. These processes not only maintain normal stem cell phenotypes but also contribute to the development of some types of solid tumors (Klymkowsky $\&$ Savagner 2009). Several transcription factors, such as
ZEB1, TWIST, and SNAIL1, have been identified as inducers of the EMT/MET processes, and are known to play a role in cancer progression and metastasis (Montserrat et al. 2011). ZEB1 is a master key in these processes. It has been associated with the maintenance of stem cell characteristics through expression of microRNAs and through the inhibition of the sonic hedgehog pathway (Wellner et al. 2009, Tang et al. 2012).

Another gene that is involved in the MET process is BIRC5 (survivin), a member of the apoptosis inhibitor family. BIRC5 (survivin) is highly expressed in fetal tissue and in most human solid tumors. Its expression is abolished in non-tumor cells and mature cells. Detection of BIRC5 (survivin) in tumors derived from human embryonic stem cells, such as teratoma, indicates that it plays a role in the formation of these tumors and their maintenance by transforming normal embryonic stem cells into embryonic cell-like cells (Brabletz et al. 2005, Boidot et al. 2008, Blum et al. 2009). BIRC5 (survivin) has also been shown to be involved in growth arrest, reduced migration, and resistance to chemotherapy- and radiotherapy-induced apoptosis (Tirrò et al. 2006, Nabzdyk et al. 2011).

However, the link between the expression of the $A B C G 2 / B C R P$ transporter gene and genes related to EMT processes in aggressive thyroid tumors is unknown. The aim of the present study was to investigate whether the expression of the $A B C G 2 / B C R P$ transporter gene is associated with ZEB1 and other EMT-related genes involved in tumor dedifferentiation using a papillary cell line (thyroid papillary carcinoma (TPC-1)) as a cellular model.

\section{Subjects and methods}

\section{TPC-1 cell culture and cellular selection}

The TPC-1 cell line was provided by Dr Paolo Vigneri (University of Catania, Italy). The short tandem repeat (STR) profiling was carried out using the protocols for the GeneAmp PCR System 2400 Thermal Cycler (Perkin Elmer/Applied Biosystems, Waltham, MA, USA) and the ABI PRISM 310 Genetic Analyzer (Perkin Elmer/Applied Biosystems) according to the manufacturer's instructions. STR profiles were analyzed using the software package Genemapper 4.1 (Applied Biosystems). The TPC-1 cell line was matched with its STR profiles reported in previous studies (Meireles et al. 2007). This cell line was cultured in RPMI 1640 (w L-glutamine) supplemented with 10\% fetal bovine serum and $2 \%$ streptomycin/penicillin.

Published by Bioscientifica Lto. 
To enrich the ABCG2/BCRP-positive cells in the TPC-1 cell cultures and to generate a TPC-1 MITO-resistant subline, we used mitoxantrone, a specific substrate of ABCG2/BCRP. Mitoxantrone was diluted to $12 \mu \mathrm{M}$ in the RPMI (low glucose) basal medium and was added to the culture every 2 days, following the protocol described by Mato et al. (2009). Cell cultures were maintained in $5 \% \mathrm{CO}_{2}$ at $37{ }^{\circ} \mathrm{C}$ in a humidified incubator. The surviving cells were then placed in fresh RPMI medium (low glucose; Gibco-BRL) supplemented with 10\% FCS and 5\% glutamine. Expression of $A B C G 2 / B C R P$ transporters was confirmed using the qRT-PCR technique before and after cell selection.

\section{Human thyroid tissue samples}

Thyroid tumor tissue samples $(n=34)$ were collected from patients undergoing surgery at Hospital de la Santa Creu i Sant Pau (Barcelona, Spain). The study was approved by the Local Ethics Committee and carried out in accordance with the Declaration of Helsinki. Table 1 shows patient data: sex, age at diagnosis, tumor histology, and tumor stage defined by recent international guidelines (Cooper et al. 2009). Diagnosis of underlying disease was verified by histological examination 7 days after surgery.

\section{RNA isolation and first strand cDNA synthesis}

Total RNAs obtained from the human tissues and cell lines were isolated using the TRIzol reagent according to the manufacturer's instructions (Invitrogen). The RNA yield and the ratio of absorbance at $260-280 \mathrm{~nm}\left(\mathrm{~A}_{260}: \mathrm{A}_{280}\right.$ ratio $)$

Table 1 Characteristics of patients with malignant thyroid lesions. Tumor stage defined by the recent international guidelines (Cooper et al. 2009)

\begin{tabular}{|c|c|}
\hline Mean age at diagnosis & 59.7 (22-83 years) \\
\hline \multicolumn{2}{|l|}{$\operatorname{Sex}(n)$} \\
\hline Female & 30 \\
\hline Male & 4 \\
\hline \multicolumn{2}{|l|}{ Histology } \\
\hline WDTC (papillary) & 31 \\
\hline PDTC & 2 \\
\hline ATC & 1 \\
\hline \multicolumn{2}{|l|}{ Stage $(n)$} \\
\hline Stage I & 13 \\
\hline Stage II & 5 \\
\hline Stage III & 6 \\
\hline Stage IV & 7 (plus two PDTC and one ATC) \\
\hline
\end{tabular}

WDTC, well-differentiated thyroid carcinoma, PDTC, poorly differentiated thyroid carcinoma; ATC, anaplastic thyroid cancer. were measured using a NanoDrop ND-1000 Spectrophotometer (NanoDrop Technologies, Montchanin, DE, USA) and the RNA quality was checked by electrophoresis using agarose gels. Total RNA $(1 \mu \mathrm{g})$ was reverse transcribed using the Transcriptor First-Strand cDNA Synthesis Kit (Roche Applied Science). cDNA samples were stored at $-20{ }^{\circ} \mathrm{C}$ and diluted with RNase-free water for use as template in real-time PCR analysis.

\section{Quantitative real-time PCR (qRT-PCR) and RT-PCR}

Real-time PCR was conducted using an ABI PRISM 7900HF Sequence Detection System, according to the manufacturer's protocol (Applied Biosystems). All reactions were carried out using $100 \mathrm{ng}$ of cDNA in a total volume of $50 \mu$ l of TaqMan Universal PCR Master Mix (Applied Biosystems) and the predesigned and labeled primer/probe set (Assays-on-Demand Gene Expression assay, Applied Biosystems). The samples were analyzed in duplicate, negative controls were included, and PCR products were verified using dissociation curve analysis immediately after RT-PCR. The GADPH housekeeping gene was used to normalize gene expression data. The relative changes in gene expression were analyzed by the $2^{-\Delta \Delta C t}$ method and SDS2.1 and Data Assist V2.1 Software (Applied Biosystems). TaqMan qPCR primers (Applied Biosystems) used in the study were as follows: ABCG2/BRCP (Hs0105379_m1), ZEB1 (Hs01566407_m1), SNAIL1 (Hs00195591_m1), TWIST (Hs003611867_m1), E-cadherin (CDH1) (Hs00 170423_m1), N-cadherin (CDH2, Hs00983056_m1), integrin $\beta 1$-binding protein 1 (ITGB1BP1, Hs00178055_m1), ITGB1 (Hs00559595_m1), survivin (BIRC5, Hs00977611 g1), vimentin (VIM, Hs00185584), and GAPDH (4333764F). Commercially available RNA pooled from normal thyroid (636536, Clontech) was used as a control in the real-time PCRs (qRT-PCRs).

\section{siRNA transfection}

siRNA transfection in TPC-1 parental cell lines and in the TPC-1 MITO-resistant subline was carried out using Lipofectamine RNAiMAX transfection reagent (Life Technologies) according to the manufacturer's protocol. Approximately $4.5 \times 10^{5}$ cells were plated in six-well plates overnight. The next day, the cells were transiently transfected with either $10 \mathrm{nM}$ predesigned siRNA (Stealth Select RNAi) targeting ZEB1 (sc38643) or control siRNA purchased from Invitrogen. The transfected cells were harvested at 24,48 , and $72 \mathrm{~h}$ for further analyses. The efficiency of the siRNA transfection showed a significant

Published by Bioscientifica Ltd. 
reduction in ZEB1 mRNA expression level $(P<0.001$; Supplementary Fig. 1, see section on supplementary data given at the end of this article). Each assay was carried out in triplicate in at least three independent experiments.

\section{Immunocytochemistry}

Cytospin slides from cell suspensions of the TPC-1 parental cell line and TPC-1 MITO-resistant subline were immunostained. Samples were then fixed in $4 \%$ paraformaldehyde and rinsed with PBS solution. They were then blocked for $10 \mathrm{~min}$ at room temperature in a solution containing $1 \%$ BSA and $0.2 \%$ saponin. The primary antibodies and their dilutions were as follows: ZEB1 (HPA027524, Sigma-Aldrich), vimentin (MAB3400, Millipore, Darmstadt, Germany), and TWIST (sc-6269, Santa Cruz Biotechnology, Inc., Dallas, Texas, USA) at $1 / 100$, E-cadherin (M3612, Dako, Glostrup, Denmark), N-cadherin (M3613, Dako), ITGB1 (610468, Becton Dickinson, East Rutherford, New Jersey, USA), SNAIL1 (sc-10433, Santa Cruz Biotechnology, Inc.) at 1/50, and ABCG2/BCRP (AB3380, Abcam, Cambridge, UK) at 1/1000. All antibodies were diluted with a blocking solution (s3022, Dako) and incubated overnight $(\mathrm{O} / \mathrm{N})$ at $4{ }^{\circ} \mathrm{C}$. Biotinylated second antibody and peroxidaseconjugated streptavidin from the Dako Universal LSAB Kit (Dako) were added for 20 min each. Finally, sections were incubated in 3/3-diaminobenzidine for $5 \mathrm{~min}$, followed by hematoxylin counterstaining and mounting. Negative controls were prepared by replacing the primary antibody with non-immune serum. No signals were observed for these samples. The results were visualized with a Leica microscope.

\section{Flow cytometry analysis}

Subconfluent cells were harvested using trypsin and $1 \times 10^{6}$ cells were incubated with the primary antibody anti-BCRP, clone 5D3 (MAB4155, Millipore), for $60 \mathrm{~min}$ at $4{ }^{\circ} \mathrm{C}$ and washed twice with PBS $+2 \%$ FCS. FITC-conjugated secondary antibody (ab6785, Abcam) was applied to the cells for $30 \mathrm{~min}$ at $4{ }^{\circ} \mathrm{C}$. Briefly, cells were washed twice with $\mathrm{PBS}+2 \% \mathrm{FCS}$, and resuspended in $0.5 \mathrm{ml}$ PBS with 10\% FCS. Labeled cells were scanned on a FACSCalibur Cytometer (Becton Dickinson) and analyzed using Cellquest Software (Becton Dickinson), acquiring $1 \times 10^{4}$ events. An isotopic control immunoglobuolin (ab11-4732, eBioscience, San Diego, CA, USA) was used as a negative control.

\section{In vitro wound healing assay}

TPC-1 parental cells, the TPC-1 MITO-resistant subline, and the TPC-1 MITO-resistant subline transfected with ZEB1 siRNA were plated at high densities and grown to confluence at $90 \%$ overnight. The cells were scratched with a pipette tip $(10 \mu \mathrm{l})$ and washed several times to remove the cellular debris. Using an inverted microscope, the wounds were photographed at $0 \mathrm{~h}(t=0)$ and again after $16 \mathrm{~h}$ of incubation, at the same site, at $37^{\circ} \mathrm{C}$. The cultures were incubated with serum-free medium. Image J Software (National Institutes of Health, Bethesda, MD, USA) was used to analyze photographs. The percentage of wound healing was determined based on three measurements of the wound area. Each result is the mean of three independent experiments.

\section{Invasion assay}

TPC-1 $\left(2 \times 10^{5}\right)$ in serum-free DMEM was placed in an insert made of polycarbonate membrane with $8-\mu \mathrm{m}$ pores and precoated with basement membrane matrix (Cell Biolabs, Inc., San Diego, CA, USA) following the manufacturer's protocol. The outer chamber was filled with $500 \mu \mathrm{l}$ RPMI containing 10\% FCS as the chemoattractant. The chambers were then placed in an incubator at $37{ }^{\circ} \mathrm{C}$ with $95 \% \mathrm{O}_{2}+5 \% \mathrm{CO}_{2}$ for 3 days. The inserts were removed, and the noninvading cells were removed using cotton-tipped swabs. The cells that traversed the membrane pore and spread to the lower surface of the filters were stained with eosin for visualization, and the number of cells that penetrated the membrane was determined by counting the mean cell number of three randomly selected high-power fields (200×; MOTIC AE31). Experiments were carried out in triplicate. The results for the TPC-1 MITO-resistant subline alone and transfected with ZEB1 siRNA were normalized to the values for TPC-1 parental cells.

\section{Statistical analysis}

Results are expressed as mean \pm s.D. The statistical significance was estimated using Student's unpaired $t$-test. Pairwise comparisons were made using Student's t-test. A two-tailed $P<0.05$ was considered statistically significant. The analyses were performed using DATA ASSIST Software, version 3.01 or GraphPad Prism for Windows, version 4.0 (GraphPad Software, San Diego, CA, USA).

Published by Bioscientifica Ltd. 


\section{Results}

Establishment and characterization of the TPC-1 MITO-resistant subline compared with the TPC-1 cell line used as a control: relative expression of the $A B C G 2 / B C R P$ transporter gene and genes related to the EMT process

Stem cell markers analyzed by immunocytochemistry showed a few TPC-1 cells with a weak protein expression for $A B C G 2 / B C R P$ and nestin, and a high protein level for the $C D 133$ marker. After cell selection, the TPC-1 MITOresistant cell subline showed an increase in protein expression for $A B C G 2 / B C R P$ but no changes in protein expression for the other markers tested (Fig. 1A). Immunocytochemistry results for the $A B C G 2 / B C R P$ gene correlated with a significant increase in the relative expression of mRNA detected for the $A B C G 2 / B C R P$ gene (eightfold change, $P<0.05$; Fig. 1B) and a higher mean fluorescence
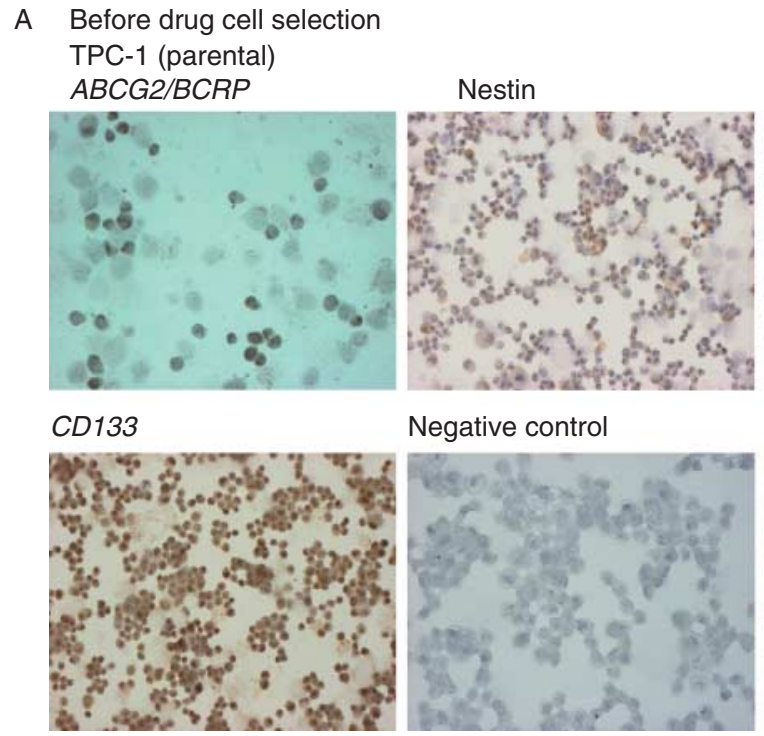

Negative control
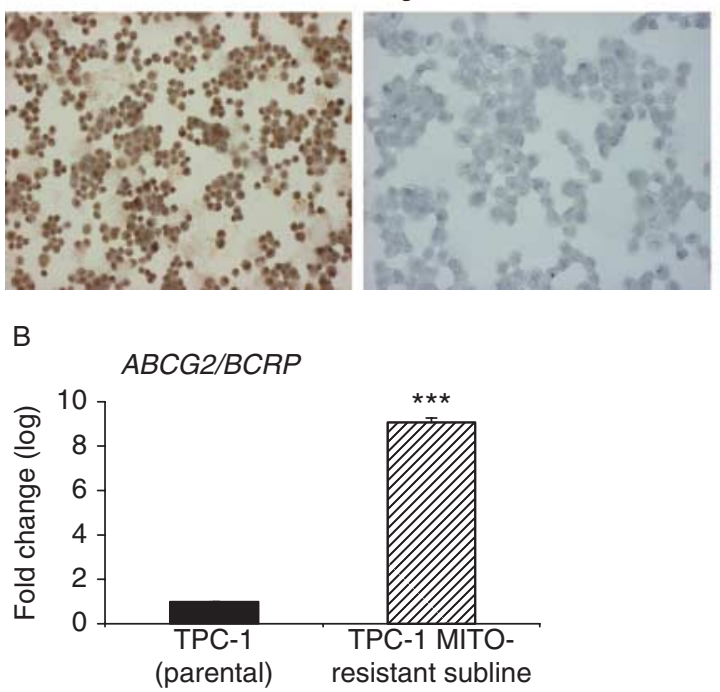

Figure 1

Characterization of TPC-1 parental cells and the TPC-1 MITO-resistant subline. (A) Representatives images of cell stained for $A B C G 2 / B C R P$, nestin, and $C D 133$ in both before and after drug selection (20× magnification). (B) Relative expression levels of mRNA for the ABCG2/BRCP gene. Data are representative of three independent experiments. Data shown represent intensity measured by flow cytometry $(P<0.05$; Fig. $1 C)$. We also observed a significant increase in expression of the ZEB1 and TWIST genes (35-fold change $(P<0.05)$ and a 15 -fold change $(P<0.05)$ respectively) in the same selected cell population. No significant change was observed in SNAIL1 expression in TPC1 or in the TPC-1 MITO-resistant subline (Fig. 2A), indicating a good correlation with the protein levels detected by immunocytochemistry (Fig. 2B). After cell selection, the TPC-1 MITO-resistant cell subline showed an increase in $\mathrm{N}$-cadherin gene expression (twofold change, $P<0.01$; Fig. $3 \mathrm{~A}$ ). The results for $\mathrm{N}$-cadherin gene expression were correlated with protein expression (Fig. 3B). No expression of the E-cadherin gene was observed in the TPC- 1 or the TPC-1 MITO-resistant subline (data not shown) and the result for gene expression of E-cadherin was confirmed by immunocytochemical analysis (Fig. 3B). The analysis of ITGB1 and

\section{After drug cell selection}

TPC-1 MITO-resistant subline

ABCG2/BCRP Nestin

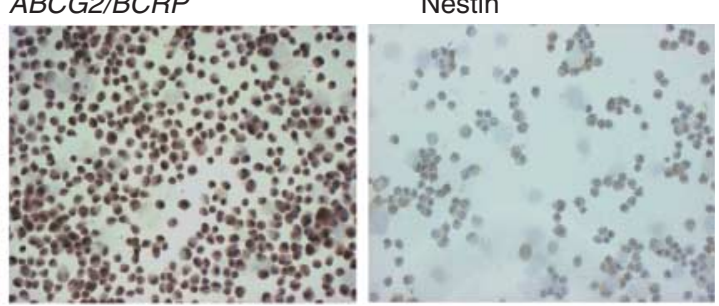

$C D 133$

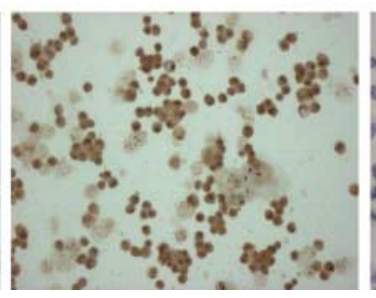

Negative control
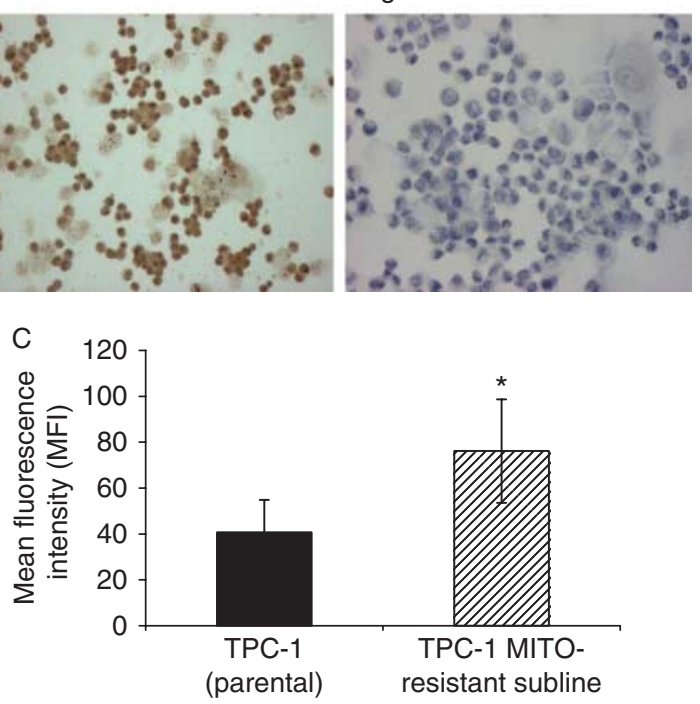

the mean \pm s.D. for three independent experiments for mRNA expression, $* * * P<0.001$. (C) Mean intensity of flourescence (MIF) of TPC-1 parental cells vs the TPC-1 MITO-resistant subline. Bars represent mean \pm s.D. from three separate experiments $\left({ }^{*} P<0.05\right)$.

Published by Bioscientifica Ltd. 
A
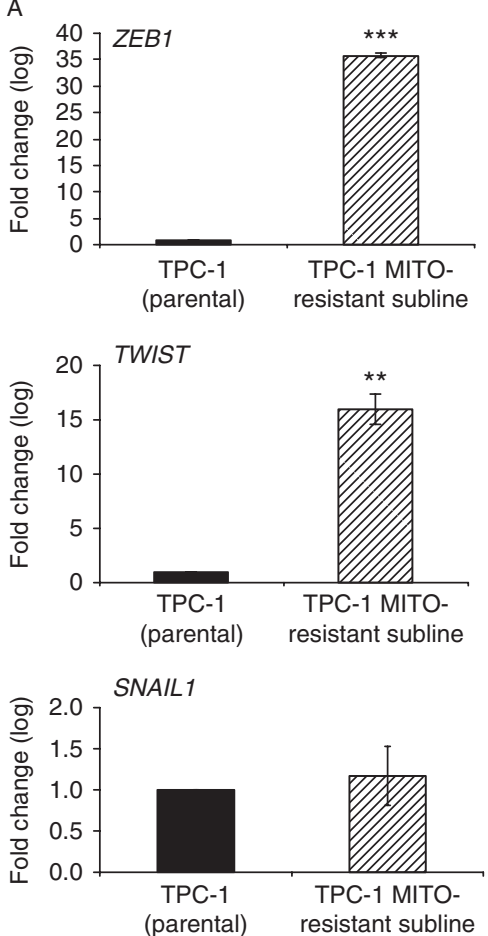

B

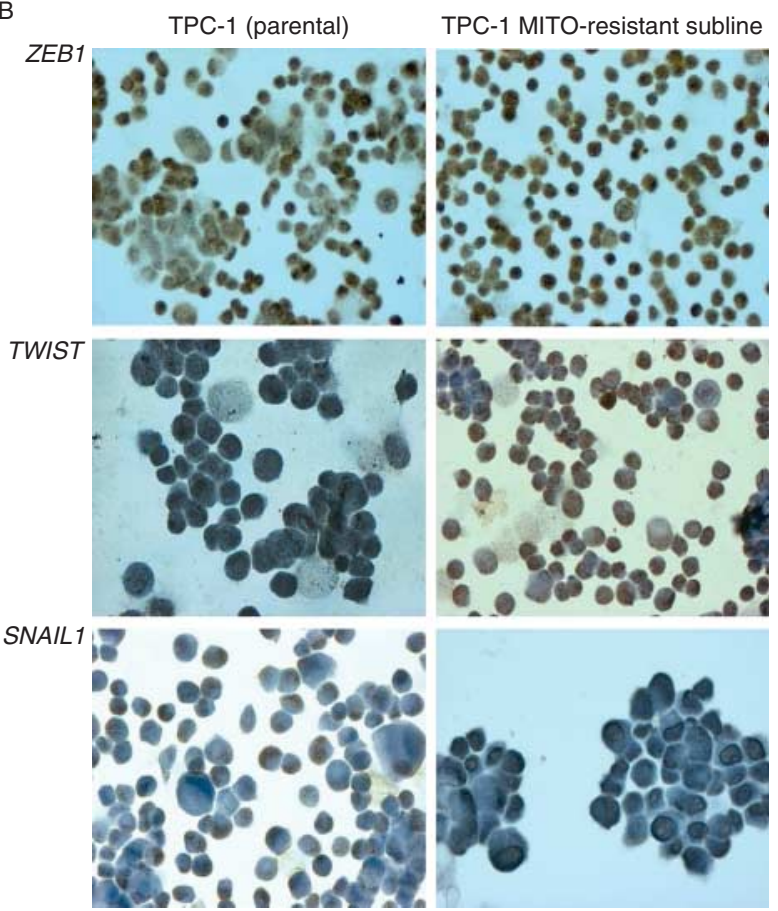

\section{Figure 2}

Relative expression of protein and mRNA transcription factors: ZEB1, TWIST, and SNAIL1 in TPC-1 parental cells and the TPC-1 MITO-resistant subline. (A) qRT-PCR analysis shows a significant higher expression at the mRNA level ZEB1 and TWIST in the TPC-1 MITO-resistant subline. Significant changes were observed in ZEB1 $(* * * P<0.001)$ and TWIST $(* * P<0.01)$ genes. No significant change in SNAIL1 gene expression was found.

integrin cytoplasmic domain-associated protein 1 molecule (ITGB1BP1) showed significant downregulation of the relative expression in selected cells (twofold lower for both genes) compared with parental cells $(P<0.05)$ (Fig. $4 \mathrm{~A}$ and $\mathrm{B}$ ). No significant changes were detected in the relative expression of vimentin at both the mRNA and protein levels (Fig. 4C and D).

\section{Effects of silencing of the ZEB1 gene on EMT-related genes in the TPC-1 MITO-resistant cell subline}

The effects of silencing of the ZEB1 gene at $48 \mathrm{~h}$ on EMTrelated genes resulted in a significant induction of E-cadherin gene expression (eightfold change, $P<0.001$ ) and nuclear localization of E-cadherin protein in 35\% of cells (Fig. 5A and B). In contrast, vimentin gene expression showed significant downregulation at $24 \mathrm{~h}$ (twofold change, $P<0.05)$ and an even higher downregulation at $48 \mathrm{~h}$ (fourfold change, $P<0.001$ ), although some expression remained (Fig. $5 \mathrm{C}$ and D). After silencing of the ZEB1 gene for $24 \mathrm{~h}$, analysis of $A B C G 2 / B C R P$ gene
Bars represent mean \pm s.D. from three separate experiments. TPC -1 cells were used as a control. (B) Representative images of cells stained for ZEB1 ( $20 \times$ magnification), TWIST1, and SNAIL1 ( $40 \times$ magnification) by immunocytochemistry both before (TPC-1 parental cells) and after mitoxantrone selection (TPC-1 MITO-resistant subline).

expression showed a significant upregulation (twofold change, $P<0.01)$. However, a significant reduction in $A B C G 2 / B C R P$ gene expression was noted at 48 and $72 \mathrm{~h}$, although some expression remained (fourfold lower, $P<0.05$; Fig. 6A). A significant downregulation at $24 \mathrm{~h}$ was observed in $\mathrm{N}$-cadherin gene expression (fourfold lower, $P<0.05)$ and was maintained at 48 and $72 \mathrm{~h}$ (Fig. 6B). Significant upregulation of ITGB1 gene expression was detected at 48 and $72 \mathrm{~h}$ (twofold change and 2.5-fold change, $(P<0.01)$, respectively; Fig. 6C). The ITGB1BP1 (ICAP1) molecule interacted with ITGB1 and had a low level of expression in the TPC-1 MITOresistant cell subline at 24 and $48 \mathrm{~h}$. This molecule exhibited high upregulation at $72 \mathrm{~h}$ (12-fold change, $P<0.05$; Fig. 6D).

\section{Effect of the ZEB1 knockdown on survivin (BIRC5) gene expression in cell migration and invasion}

The survivin gene was expressed in the parental TPC-1 cell line, but it showed a statistically significant upregulation

Published by Bioscientifica Ltd 

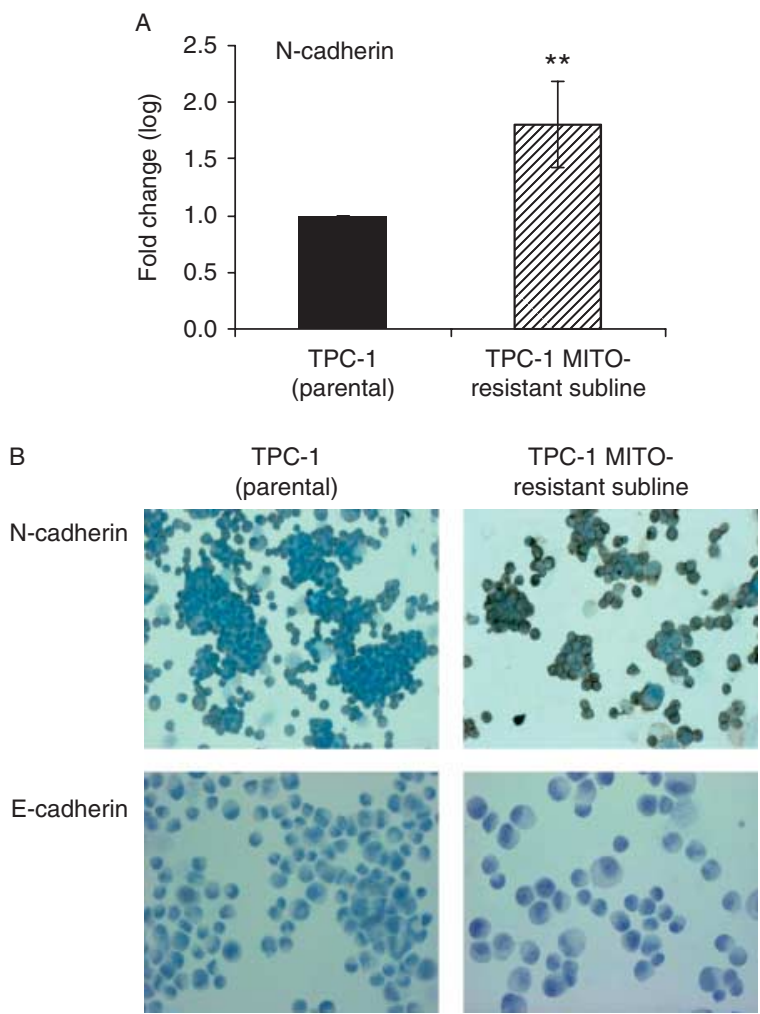

\section{Figure 3}

Relative expression of mRNA and protein for $\mathrm{N}$ - and E-cadherin in TPC-1 parental cells and the TPC-1 MITO-resistant subline. (A) qRT-PCR analysis shows a significant increase in expression of $\mathrm{N}$-cadherin in the TPC-1 MITOresistant subline (twofold change, $* * P<0.01$ ). Bars represent mean \pm s.D. from three separate experiments. TPC-1 parental cells were used as a control. (B) Representative image of cells stained for $\mathrm{N}$-cadherin ( $20 \times$ magnification) and E-cadherin ( $20 \times$ magnification) by immunocytochemical staining both before and after drug selection.

in the TPC-1 MITO-resistant subline (twofold change, $P<0.05$; Fig. 7A). The ability to close a wound, analyzed by wound-healing assays, showed a statistically significantly faster migration in the TPC-1 MITO-resistant subline cells
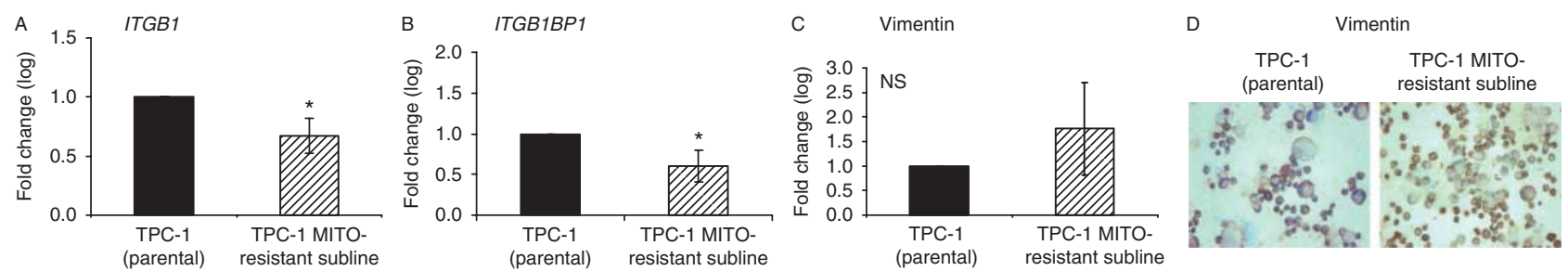

\section{Relative expression of mRNA ABCG2/BCRP transporter, and EMT-related genes in human thyroid carcinoma tissues}

The analysis of gene expression carried out in a cohort of 34 patients with different stages of the disease (see Table 1) showed a statistically significant upregulation in the relative expression of the ABCG2/BCRP, SNAIL1, TWIST1, and ZEB1 genes compared with control tissue $(P<0.05)$. These results correlated with the stage of the tumors (Fig. 9A, B, C and D). The analysis of E- and $\mathrm{N}$-cadherin genes showed a statistically significant upregulation for both genes (tenfold change and 11-fold change respectively $(P<0.05))$ in patients with stages I and II of the disease. In contrast, downregulation (fourfold change) was statistically significant for both genes in patients with stages III and IV disease. (Fig. 9E and F).

\section{Discussion}

In this study, we identified for the first time, to our knowledge, cells positive for ABCG2/BCRP, nestin, and CD133 in a papillary cell line (TPC-1). However, we did

\section{Figure 4}

Relative expression of mRNA and protein for ITGB1, ITGB1BPA, and vimentin in TPC-1 parental cells and the TPC-1 MITO-resistant subline. ( $A, B$ and C) qRT-PCR analysis shows a significant downregulation of the expression of ITGB1 and ITGB1P1 (twofold change, *P<0.05). No significant change in the expression of the vimentin gene was observed in selected cells. Bars represent mean \pm s.D. from three separate experiments. TPC-1 parental cells were used as a control. (D) Representative image for vimentin $(20 \times$ magnification) stained by immunocytochemistry both before (TPC-1 parental cells) and after mitoxantrone selection (TPC-1 MITOresistant subline).

Published by Bioscientifica Ltd. 
A

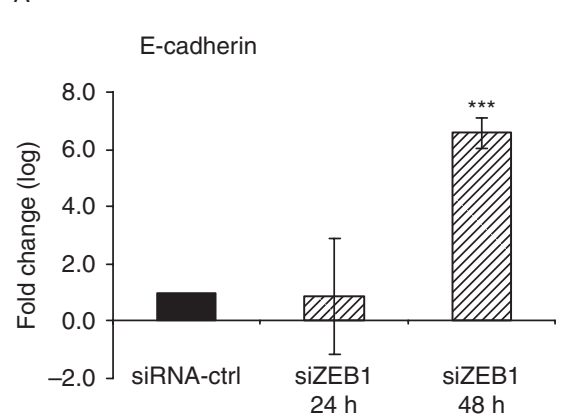

C

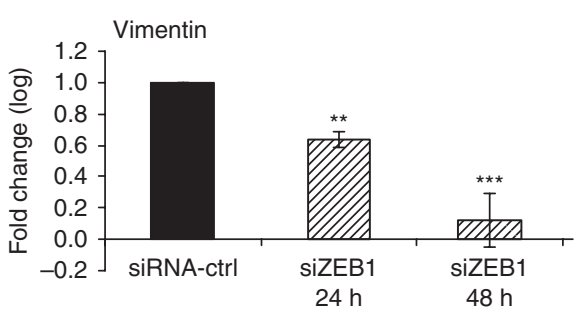

B

E-caherin

D

Vimentin
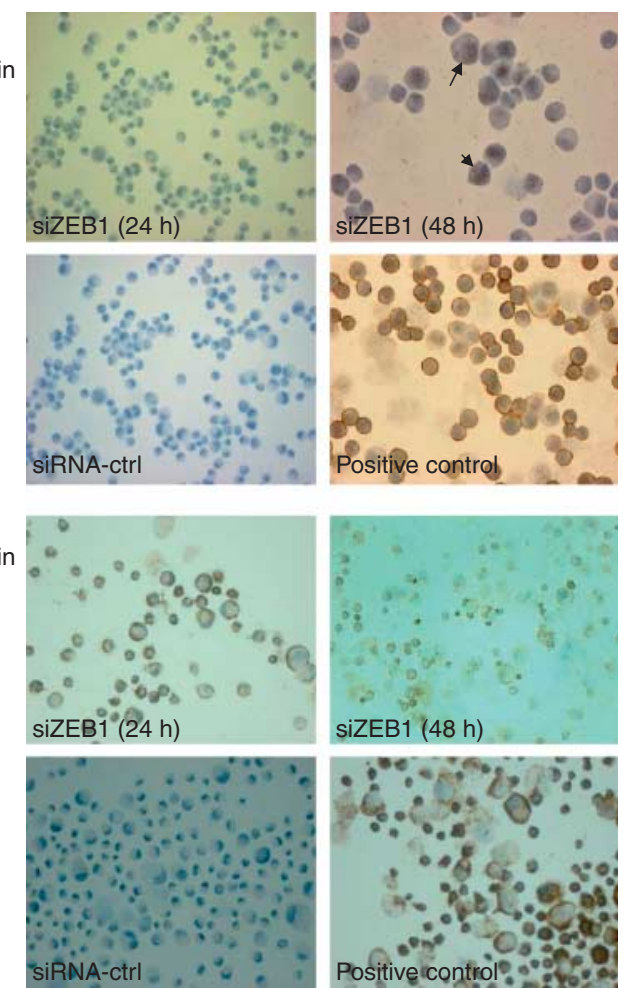

\section{Figure 5}

Effect of knockdown of ZEB1 on EMT inducer genes (E-cadherin and vimentin). (A) qRT-PCR analysis showed a significant increase in the expression of the mRNA for the E-cadherin gene $(* * * P<0.001)$.

(B) Representative image of cells positively stained for $\mathrm{E}$-cadherin protein showing nuclear. The arrows indicate staining at $48 \mathrm{~h}$ of ZEB1 silencing (20× magnification). (C) qRT-PCR analysis showed a significant reduction

not detect changes in gene expression for nestin or CD133 genes after enriching the cell culture with cells that expressed the $A B C G 2 / B C R P$ gene, indicating that more than one cell population has a pluripotent capacity in
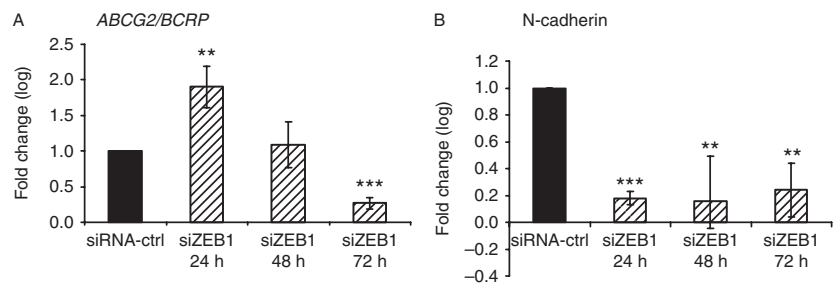

\section{Figure 6}

Effect of knockdown of ZEB1 on the relative expression of mRNA for $A B C G 2 / B C R P$, N-cadherin, ITGB1, and ITGB1BP1 at 24, 48, and $72 \mathrm{~h}$. (A) Knockdown of $Z E B 1$ resulted in upregulation of $A B C G 2 / B C R P$ gene expression at $24 \mathrm{~h}(* * P<0.01)$. This increment was decreased at 48 and at $72 \mathrm{~h}$, a reduction of expression was detected $(* * * P<0.001)$.

(B) Downregulation of $\mathrm{N}$-cadherin was detected at $24 \mathrm{~h}$ of $Z E B 1$ silencing $(* * * P<0.001)$ and was maintained at 48 and $72 \mathrm{~h}(* * P<0.01)$. of expression at 24 and $48 \mathrm{~h}$ of silencing of ZEB1 for vimentin mRNA $(* * P<0.01$ and $* * * P<0.001)$. (D) Representative image showed a reduction of expression of protein at $48 \mathrm{~h}$ of silencing of ZEB1 ( $20 \times$ magnification). Bars represent mean \pm s.D. from three separate experiments. The TPC-1 MITO-resistant subline transfected with siRNA control was used as a control.

TPC-1. Furthermore, we observed, for the first time, a relationship between the increase in expression of the adult stem marker $A B C G 2 / B C R P$ gene, a member of the ATP-binding cassette transporters and EMT inducer genes,
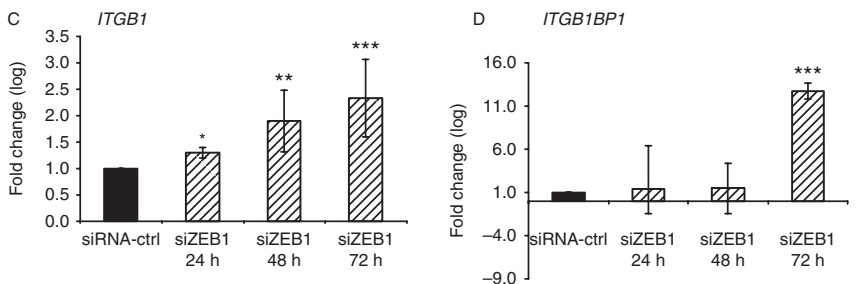

(C) The relative mRNA expression of ITGB1 showed an upregulation at $24 \mathrm{~h}$ $(* P<0.05), 48 \mathrm{~h}(* * P<0.001)$, and $72 \mathrm{~h}(* * * P<0.001)$. (D) The relative mRNA expression of ITGB1BP1 gene showed an upregulation of gene expression at $72 \mathrm{~h}(* * * P<0.001)$. Bars represent mean \pm s.D. from three separate experiments. The TPC-1 MITO-resistant subline transfected with siRNA was used as a control.

Published by Bioscientifica Ltd. 

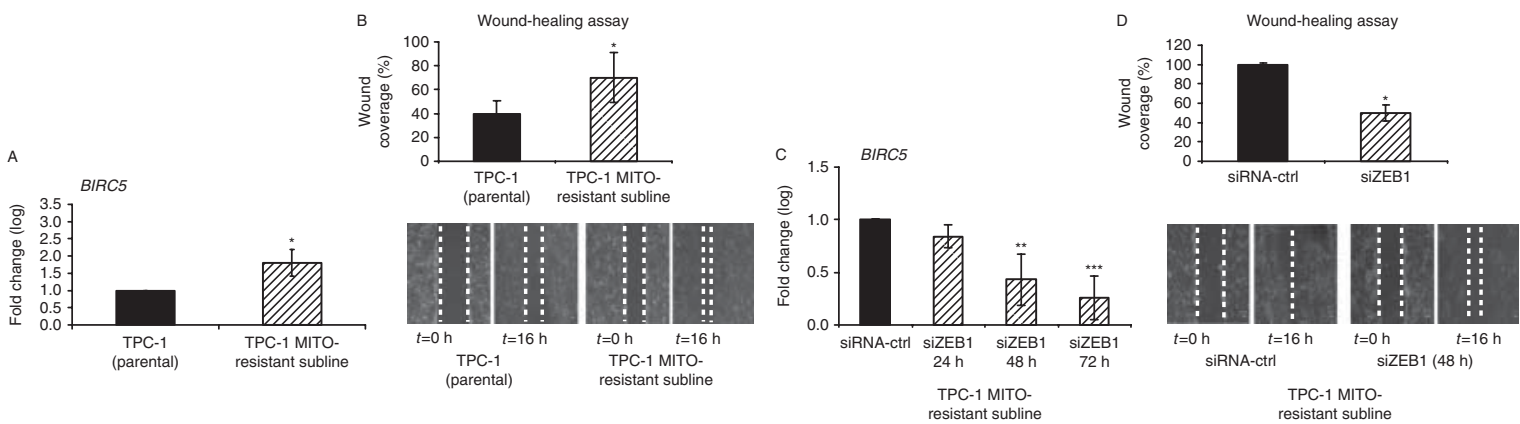

\section{Figure 7}

Analysis of survivin (BIRC5) gene expression, cellular migration in TPC-1 parental cells. The TPC-1 MITO-resistant subline, and the TPC-1 MITOresistant subline trasnsfected with siRNA ZEB1. (A) The relative mRNA expression of survivin gene showed upregulation in selected cells (TPC-1 MITO-resistant subline cells; twofold change, $* P<0.05$ ). (B) The woundhealing assay showed significantly faster migration in the TPC-1 MITOresistant subline compared with TPC- 1 parental cells $(* P<0.05)$. The images were obtained by phase-contrast microscope $(100 \times)$. (C) Transient ZEB1

in TPC-1 and in papillary thyroid tumors. Although there is evidence that the EMT process generates CSCs, the connection between the specific genes involved in this process and the radioresistance observed in thyroid knockdown resulted in downregulation of BIRC5 gene expression at $48 \mathrm{~h}$ $(* * P<0.01)$ and at $72 \mathrm{~h}(* * * P<0.001)$. (D) The wound-healing assay showed a significant decrease in the closed wound area in the TPC-1 MITOresistant subline transfected with siRNA ZEB1 compared with the TPC-1 MITO-resistant subline transfected with siRNA control $(* P<0.05)$. Phasecontrast microscope images $(\times 100)$. Bars represent mean \pm s.D. from four separate experiments.

tumors has not been clearly established (Visvader \& Lindeman 2008, Singh \& Settleman 2010, Chu et al. 2013, Lan et al. 2013). Recent research using anaplastic thyroid cancer as a model has confirmed an association

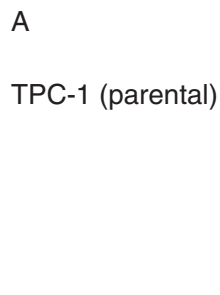

TPC-1 MITOresistant subline
$48 \mathrm{~h}$
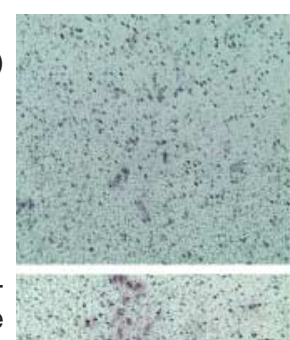

$72 \mathrm{~h}$

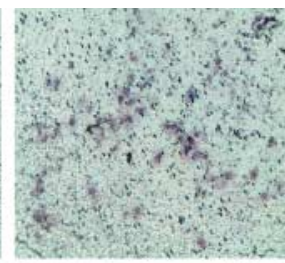

$96 \mathrm{~h}$
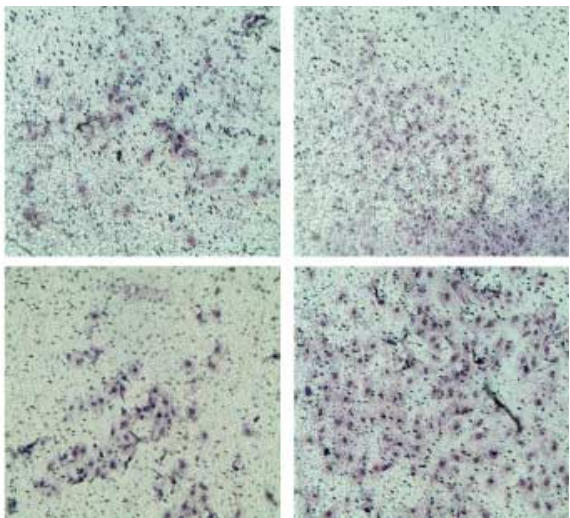

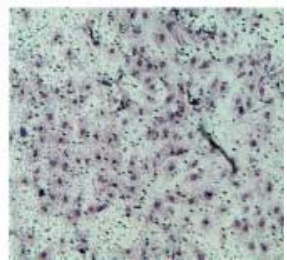

B

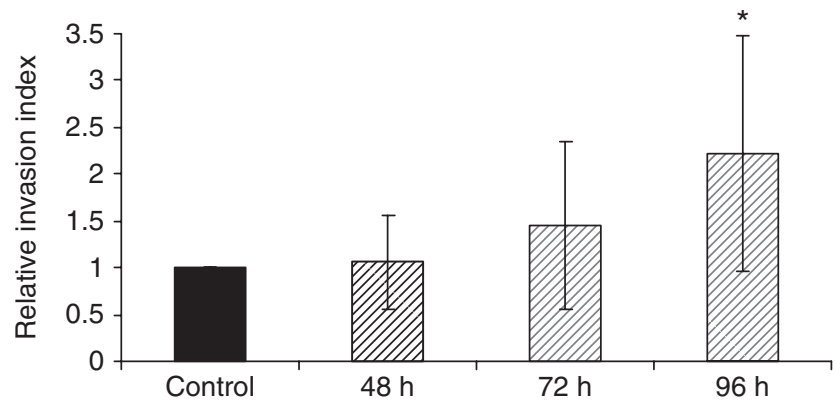

\section{Figure 8}

Transwell invasion ability of TPC-1 parental cells and TPC-1 MITO-resistant subline cells. (A and B) The ability to invade surrounding extracellular matrigel was analyzed at 48,72 , and $92 \mathrm{~h}$ of cell culture in complete

http://jme.endocrinology-journals.org DOI: 10.1530/JME-14-0051
(C) 2014 Society for Endocrinology Printed in Great Britain medium. The TPC-1 MITO-resistant subline cells showed a high capacity for invasion at $92 \mathrm{~h}\left({ }^{*} P<0.05\right)$ compared with TPC-1 parental cells used as a control. Bars represent mean \pm s.D. from four separate experiments.

Published by Bioscientifica Ltd. 
A
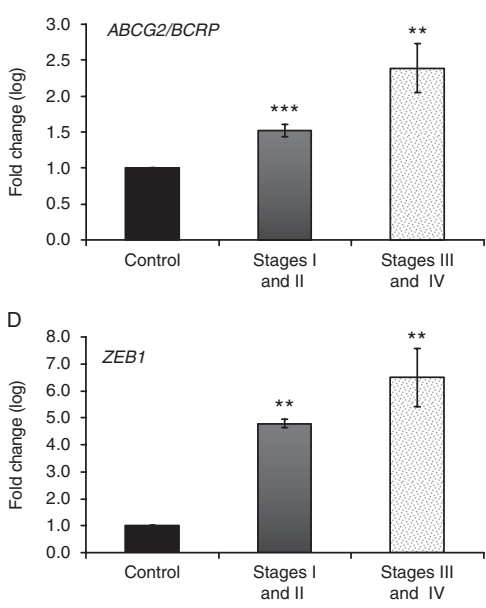

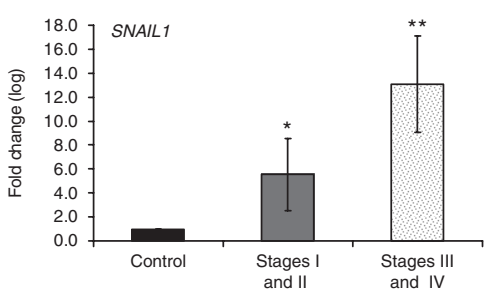

$\mathrm{E}$

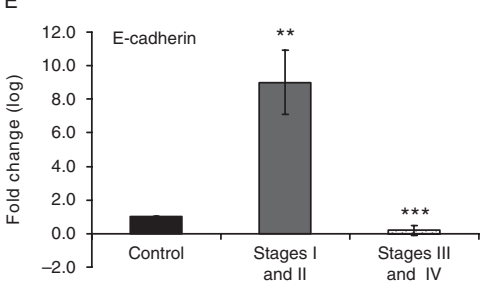

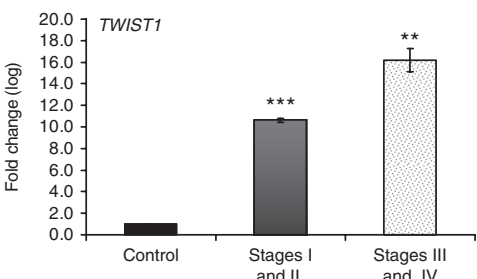

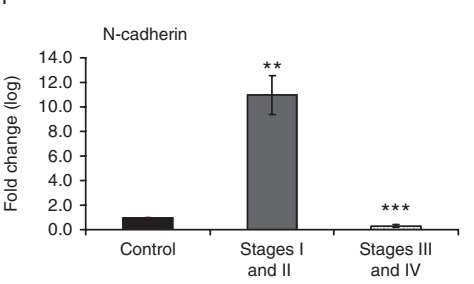

\section{Figure 9}

Gene expression of EMT inducer genes (ZEB1, SNAIL1, and TWIST1). E-cadherin, N-cadherin, and $A B C G 2 / B C R P$ from human thyroid carcinoma (papillary tumors and poorly differentiated/anaplastic tumours). (A, B, C and $D$ ) The relative mRNA expression of $A B C G 2 / B C R P, S N A I L 1, T W I S T 1$, and ZEB1 showed a higher increase in expression in tumors from patients with aggressive stages (III and IV) in comparison with those with the more benign stages (I and II). ( $\mathrm{E}$ and $\mathrm{F}$ ) The relative mRNA expression of $\mathrm{E}$ - and

between the stem-like phenotype and chemotherapy resistance, indicating that the multidrug transporter system is responsible for this chemotherapy effect (Zito et al. 2008, Davies et al. 2011, Carina et al. 2013). Our results indicate that the cell subpopulation identified in TPC-1 expresses the $A B C G 2 / B C R P$ gene, possibly contributing to the malignant progression of these tumors. This cell subpopulation also showed upregulation of expression of the BIRC5 gene, faster cellular migration, and greater ability for invasion when the selected cells (TPC-1 MITOresistant subline) were compared with the parental cell line (TPC-1). These results are consistent with those reported for pancreatic cancer (Arumugam et al. 2009, Wellner et al. 2009, Palena et al. 2011). It was of interest to note that this effect could be reverted when the ZEB1 gene was knocked down in the selected cells. In these selected cells, the transient silencing of the ZEB1 gene produced a downregulation of $A B C G 2 / B C R P$ and BIRC5, and reduced cell migration in vitro. These results indicate that $A B C G 2 / B C R P, Z E B 1$, and BIRC5 genes are linked and could play a role in the more aggressive behavior observed in some well-differentiated papillary tumors.

Other markers that we studied in TPC-1 cells were $\mathrm{E}$ - and $\mathrm{N}$-cadherin. These genes belong to transmembrane protein families and are involved in cell-adhesion. We found no expression of the E-cadherin gene in the TPC-1 cell line or in the TPC-1 MITO-resistant subline. However,
$\mathrm{N}$-cadherin genes showed a significant increase in expression in tumors from patients with benign stages (I and II), in contrast a decrease in expression of both genes was detected in tumors from patients with more aggressive stages (III and IV). Data shown represent the mean \pm S.D. $\star P<0.05, * * P<0.01$, and $* * * P<0.001$. The tumor tissue was compared with normal thyroid tissue.

the N-cadherin gene was increased in expression in TPC-1 MITO-resistant cells. Other authors have described a relationship between the loss of expression of the E-cadherin gene and the metastasic process. The role of expression of $\mathrm{N}$-cadherin gene in carcinomas is controversial (Hazan et al. 2004, Li et al. 2010, Shih \& Yamada 2012). In our study, we observed that transient ZEB1 silencing in the TPC-1 MITO-resistant subline promoted increased expression of E-cadherin with a nuclear localization, and downregulation of $\mathrm{N}$-cadherin. This result supports the observation that E-cadherin can translocate to the nucleus and participate in the regulation of Wntdependent genes (Kuphal \& Behrens 2006).

We also analyzed integrin transmembrane receptors, ITGB1 and integrin $\beta 1$-binding protein 1 (ICAP1), genes involved in the progression of malignancy, chemoresistance, morphogenesis, terminal cellular differentiation, and maintenance of the progenitor population in adult tissue (De Toni et al. 2006, Piwko-Czuchra et al. 2009, Wu et al. 2009, Ju et al. 2010, Shiraki et al. 2011). ICAP1 is considered to be the most specific ligand for the ITGB1 cytoplasmic domain and is involved in cellular processes such as cellular adhesion and migration (Fournier et al. 2002, Brunner et al. 2011). In selected cells, we found that both ITGB1 and ICAP1 genes were downregulated, but the $Z E B 1$ silencing gene was able to promote an up-expression in both. Further research is needed, nevertheless, to 
clarify the relationship between these genes and the ABCG2/BCRP gene.

Another novel finding in our study is that high increase in expression of the ABCG2/BCRP, SNAIL1, $T W I S T 1$, and ZEB1 genes in poorly differentiated thyroid carcinoma, anaplastic carcinoma, and papillary thyroid tumors correlated with more aggressive disease stages. However, in agreement with published results, reduced expression of the $\mathrm{E}$ - and $\mathrm{N}$-cadherin genes at stages III and IV also correlated with more aggressive stages. Studies in larger series and with a longer follow-up will be needed, however, to demonstrate whether these two genes can be considered as biomarkers of poor prognosis for papillary thyroid carcinoma.

In summary, we found that the expression of the $A B C G 2 / B C R P$ gene was associated with ZEB1 and other EMT-inducer genes involved in papillary thyroid tumor dedifferentiation. These results could be a promising starting point for improving understanding of the role of these cells in tumor progression, and a new tool for designing innovative therapeutic strategies.

\section{Supplementary data}

This is linked to the online version of the paper at http://dx.doi.org/10.1530/ JME-14-0051.

\section{Declaration of interest}

The authors declare that there is no conflict of interest that could be perceived as prejudicing the impartiality of the research reported.

\section{Funding}

This work was supported by the Spanish Fondo de Investigaciones Sanitarias (FIS) grant from the Ministry of Health and Consumer Affairs FIS09/02286 and Centro de Investigación Biomédica en Red en Bioingeniería, Biomateriales y Nanomedicina (CIBER-BBN) (Instituto de Salud Carlos III (ISCIII)).

\section{Author contribution statement}

E M and was responsible for supervision the experiment, analysis of the gene expression, statistical analysis of all data, and prepare the manuscript. $A M, J I P, C G$, and $E L$ were responsible for collection of all human samples and clinical-histological studies. O B for setting up of the experiment and technical supported. A $L$ responsible for the supervision of experiments and prepare the manuscript.

\section{References}

Akunuru S, James Zhai Q \& Zheng Y 2012 Non-small cell lung cancer stem/progenitor cells are enriched in multiple distinct phenotypic

http://jme.endocrinology-journals.org DOI: 10.1530/JME-14-0051
() 2014 Society for Endocrinology Printed in Great Britain subpopulations and exhibit plasticity. Cell Death \& Disease 3 e352. (doi:10.1038/cddis.2012.93)

Arumugam T, Ramachandran V, Fournier KF, Wang H, Marquis L, Abbruzzese JL, Gallick GE, Craig DL, McCinkey DJ \& Chou W 2009 Epithelial to mesenchymal transition contributes to drug resistance in pancreatic cancer. Cancer Research 69 5820-5828. (doi:10.1158/00085472.CAN-08-2819)

Blum B, Bar-Nur O, Golan-Lev T \& Benvenist N 2009 The anti-apoptotic gene survivin contributes to teratoma formation by human embryonic stem cells. Nature Biotechnology 27 281-287. (doi:10.1038/nbt.1527)

Boidot R, Vegran F, Jacob D, Chevrier S, Gangneux N, Taboureau J, Oudin C, Rainville V, Mercier L \& Lizard-Nacol S 2008 The expression of BIRC5 is correlated with loss of specific chromosomal regions in breast carcinomas. Genes, Chromosomes \& Cancer 47 299-308. (doi:10.1002/ gcc.20533)

Brabletz T, Jung A, Spaderna S, Hlubek F \& Kirchner T 2005 Opinion: migrating cancer stem cells - an integrated concept of malignant tumor progression. Nature Reviews. Cancer 5 744-749. (doi:10.1038/nrc1694)

Brunner M, Millon-Frémillon A, Chevalier G, Nakchbandi IA, Mosher D, Block MR, Albigès-Rizo C \& Bouvard D 2011 Osteoblast mineralization requires $\beta 1$ integrin/ICAP-1-dependent fibronectin deposition. Journal of Cell Biology 25 307-322. (doi:10.1083/jcb.201007108)

Carina V, Zito G, Pizzolanti G, Richiusa P, Criscimanna A, Rodolico V, Tomasello L, Pitrone M, Arancio W \& Giordano C 2013 Multiple pluripotent stem cell markers in human anaplastic thyroid cancer: the putative upstream role of SOX-2. Thyroid 23 829-837. (doi:10.1089/ thy.2012.0372)

Chu PY, Hu FW, Yu CC, Tsai LL, Yu CH, Wu BC, Chen YW, Huang PI \& Lo WL 2013 Epithelial-mesenchymal transition transcription factor ZEB1/ZEB2 co-expression predicts poor prognosis and maintains tumor-initiating properties in head and neck cancer. Oral Oncology 49 34-41. (doi:10.1016/j.oraloncology.2012.07.012)

Cooper DS, Doherty GM, Haugen BR, Kloos RT, Lee SL, Mandel SJ, Mazzaferri EL, McIver B, Pacini F, Schlumberger M, Sherman SI, Steward DL \& Tuttle RM 2009 Revised American Thyroid Association management guidelines for patients with thyroid nodules and differentiated thyroid cancer. Thyroid 19 1167-1214. (doi:10.1089/thy. 2009.0110)

Dalerba P, Cho RW \& Clarke MF 2007 Cancer stem cells: models and concepts. Annual Review of Medicine 58 267-284. (doi:10.1146/annurev. med.58.062105.204854)

Davies TF, Latif R, Minsky NC \& Ma R 2011 Clinical review: The emerging cell biology of thyroid stem cells. Journal of Clinical Endocrinology and Metabolism 96 2692-2702. (doi:10.1210/jc.2011-1047)

De Toni F, Racaud-Sultan C, Chicanne G, Mas VM, Cariven C, Mesange F, Salles JP, Demur C, Allouche M, Payrastre B et al. 2006 A crosstalk between the Wnt and the adhesion-dependent signaling pathways governs the chemosensitivity of acute myeloid leukemia. Oncogene $\mathbf{2 5}$ 3113-3122. (doi:10.1038/sj.onc.1209346)

Fatima S, Zhou S \& Sorrentino BP 2012 Abcg2 expression marks tissuespecific stem cells in multiple organs in a mouse progeny tracking model. Stem Cells 30 210-221. (doi:10.1002/stem.1002)

Fournier HN, Dupé-Manet S, Bouvard D, Lacombe ML, Marie C, Block MR \& Albiges-Rizo C 2002 Integrin cytoplasmic domain-associated protein $1 \alpha$ (ICAP- $1 \alpha$ ) interacts directly with the metastasis suppressor nm23$\mathrm{H} 2$, and both proteins are targeted to newly formed cell adhesion sites upon integrin engagement. Journal of Biological Chemistry $\mathbf{2 7 7}$ 20895-20902. (doi:10.1074/jbc.M200200200)

Friedman S, Lu M, Schultz A, Thomas D \& Lin RY 2009 CD $133^{+}$anaplastic thyroid cancer cells initiate tumors in immunodeficient mice and are regulated by thyrotropin. PLOS ONE 4 e5395. (doi:10.1371/journal. pone.0005395)

Hazan RB, Qiao R, Keren R, Badano I \& Suyama K 2004 Cadherin switch in tumor progression. Annals of the New York Academy of Sciences $\mathbf{1 0 1 4}$ 155-163. (doi:10.1196/annals.1294.016) 
Hoshi N, Kusakabe T, Taylor BJ \& Kimura S 2007 Side population cells in the mouse thyroid exhibit stem/progenitor cell-like characteristics. Endocrinology 148 4251-4258. (doi:10.1210/en.2006-0490)

Hundahl SA, Fleming ID, Fremgen AM \& Menck HR 1998 A National Cancer Data Base report on 53,856 cases of thyroid carcinoma treated in the U.S., 1985-1995. Cancer 83 2638-2648. (doi:10.1002/(SICI)10970142(19981215)83:12<2638::AID-CNCR31 > 3.0.CO;2-1)

Ju L, Zhou C, Li W \& Yan L 2010 Integrin $\beta 1$ overexpression associates with resistance to tyrosine kinase inhibitor gefitinib in non-small cell lung cancer. Journal of Cellular Biochemistry 111 1565-1574. (doi:10.1002/ jcb.22888)

Ke CC, Liu RS, Yang AH, Liu CS, Chi CW, Tseng LM, Tsai YF, Ho JH, Lee CH \& Lee OK 2013 CD133-expressing thyroid cancer cells are undifferentiated, radioresistant and survive radioiodide therapy. European Journal of Nuclear Medicine and Molecular Imaging 40 61-71. (doi:10.1007/s00259-012-2242-5)

Klymkowsky MW \& Savagner P 2009 Epithelial-mesenchymal transition. American Journal of Pathology 174 1588-1593. (doi:10.2353/ajpath. 2009.080545)

Krishnamurthy P \& Schuetz JD 2006 Role of ABCG2/BCRP in biology and medicine. Annual Review of Pharmacology and Toxicology 46 381-410. (doi:10.1146/annurev.pharmtox.46.120604.141238)

Krupkova O Jr, Loja T, Zambo I \& Veselska R 2010 Nestin expression in human tumors and tumor cell lines. Neoplasma 57 291-298. (doi:10.4149/neo_2010_04_291)

Kuphal F \& Behrens J 2006 E-cadherin modulates Wnt-dependent transcription in colorectal cancer cells but does not alter Wnt-independent gene expression in fibroblasts. Experimental Cell Research 312 457-467. (doi:10.1016/j.yexcr.2005.11.007)

Lan L, Luo Y, Cui D, Shi BY, Deng W, Huo LL, Chen HL, Zhang GY \& Deng LL 2013 Epithelial-mesenchymal transition triggers cancer stem cell generation in human thyroid cancer cells. International Journal of Oncology 43 113-120. (doi:10.3892/ijo.2013.1913)

Li K, He W, Lin N, Wang X \& Fan QX 2010 Downregulation of N-cadherin expression inhibits invasiveness, arrests cell cycle and induces cell apoptosis in esophageal squamous cell carcinoma. Cancer Investigation 28 479-486. (doi:10.3109/07357900903476745)

Li W, Reeb AN, Sewell WA, Elhomsy G \& Lin RY 2013 Phenotypic characterization of metastatic anaplastic thyroid cancer stem cells. PLoS ONE 8 e65095. (doi:10.1371/journal.pone.0065095)

Lin RY 2011 Thyroid cancer stem cells. Nature Reviews. Endocrinology $\mathbf{7}$ 609-616. (doi:10.1038/nrendo.2011.127)

Mato E, Lucas M, Petriz J, Gomis R \& Novial A 2009 Identification of a pancreatic stellate cell population with properties of progenitor cells: new role for stellate cells in the pancreas. Biochemical Journal 421 181-191. (doi:10.1042/BJ20081466)

Meireles AM, Preto A, Rocha AS, Rebocho AP, Máximo V, Pereira-Castro I, Moreira S, Feijão T, Botelho T, Marques RT et al. 2007 Molecular and genotypic characterization of human thyroid follicular cell carcinomaderived cell lines. Thyroid 17 707-715. (doi:10.1089/thy.2007.0097)

Mimeault M \& Batra SK 2006 Recent advances on the significance of stem cells in tissue regeneration and cancer therapies. Stem Cells $\mathbf{2 4}$ 2319-2345. (doi:10.1634/stemcells.2006-0066)

Montserrat N, Gallardo A, Escuin D, Catasus L, Prat J, Gutiérrez-Avignó FJ, Peiró G, Barnadas A \& Lerma E 2011 Repression of E-cadherin by SNAIL, ZEB1, and TWIST in invasive ductal carcinomas of the breast: a cooperative effort? Human Pathology 42 103-110. (doi:10.1016/ j.humpath.2010.05.019)

Nabzdyk CS, Lancero H, Nguyen KP, Salek S \& Conte MS 2011 RNA interference-mediated survivin gene knockdown induces growth arrest and reduced migration of vascular smooth muscle cells.
American Journal of Physiology. Heart and Circulatory Physiology 301 1841-1849. (doi:10.1152/ajpheart.00089.2011)

Palena C, Fernando RI, Litzinger MT, Hamilton DH, Huang B \& Schlom J 2011 Strategies to target molecules that control the acquisition of a mesenchymal-like phenotype by carcinoma cells. Experimental Biology and Medicine 236 537-545. (doi:10.1258/ebm.2011.010367)

Piwko-Czuchra A, Koegel H, Meyer H, Bauer M, Werner S, Brakebusch C \& Fässler R $2009 \beta 1$ Integrin-mediated adhesion signalling is essential for epidermal progenitor cell expansion. PLoS ONE 4 e5488. (doi:10.1371/ journal.pone.0005488)

Robey RW, Polgar O, Deeken J, To KW \& Bates SE 2007 ABCG2: determining its relevance in clinical drug resistance. Cancer and Metastasis Reviews 26 39-57. (doi:10.1007/s10555-007-9042-6)

Shih W \& Yamada S 2012 N-cadherin-mediated cell-cell adhesion promotes cell migration in a three-dimensional matrix. Journal of Cell Science 125 3661-3670. (doi:10.1242/jcs.103861)

Shiraki N, Yamazoe T, Qin Z, Ohgomori K, Mochitate K, Kume K \& Kume S 2011 Efficient differentiation of embryonic stem cells into hepatic cells in vitro using a feeder-free basement membrane substratum. PLOS ONE 6 e25929. (doi:10.1371/journal.pone.0024228)

Singh A \& Settleman J 2010 EMT, cancer stem cells and drug resistance: an emerging axis of evil in the war on cancer. Oncogene 29 4741-4751. (doi:10.1038/onc.2010.215)

Tang SN, Fu J, Nall D, Rodova M, Shankar S \& Srivastava RK 2012 Inhibition of sonic hedgehog pathway and pluripotency maintaining factors regulate human pancreatic cancer stem cell characteristics. International Journal of Cancer 131 30-40. (doi:10.1002/ijc.26323)

Thomas D, Friedman S \& Lin RY 2008 Thyroid stem cells: lessons from normal development and thyroid cancer. Endocrine-Related Cancer 15 51-58. (doi:10.1677/ERC-07-0210)

Tirrò E, Consoli ML, Massimino M, Manzella L, Frasca F, Sciacca L, Vicari L, Stassi G, Messina L, Messina A et al. 2006 Altered expression of c-IAP1, survivin, and Smac contributes to chemotherapy resistance in thyroid cancer cells. Cancer Research 66 4263-4272. (doi:10.1158/0008-5472. CAN-05-3248)

Todaro M, Lovino F, Eterno V, Cammareri P, Gambara G, Espina V, Gulotta G, Dieli F, Giordano S, De Maria R et al. 2010 Tumorigenic and metastatic activity of human thyroid cancer stem cells. Cancer Research 70 8874-8885. (doi:10.1158/0008-5472.CAN-10-1994)

Visvader JE \& Lindeman GL 2008 Cancer stem cells in solid tumors: accumulating evidence and unresolved questions. Nature Reviews. Cancer 8 755-768. (doi:10.1038/nrc2499)

Wellner U, Schubert J, Burk UC, Schmalhofer O, Zhu F, Sonntag A, Waldvogel B, Vannier C, Darling D, Zur Hausen AL et al. 2009 The EMTactivator ZEB1 promotes tumorigenicity by repressing stemnessinhibiting microRNAs. Nature Cell Biology 11 1487-1495. (doi:10.1038/ ncb1998)

Wu W, Kitamura S, Truong DM, Rieg T, Vallon V, Sakurai H, Bush KT, Vera DR, Ross RS \& Nigam SK 2009 $\beta 1$-Integrin is required for kidney collecting duct morphogenesis and maintenance of renal function. American Journal of Physiology. Renal Physiology 297 210-217. (doi:10.1152/ajprenal.90260.2008)

Yamada H, Takano T, Ito Y, Matsuzuka F, Miya A, Kobayashi K, Yoshida H, Watanabe M, Iwatani Y \& Miyauchi A 2009 Expression of nestin mRNA is a differentiation marker in thyroid tumors. Cancer Letters 280 61-64. (doi:10.1016/j.canlet.2009.02.006)

Zito G, Richiusa P, Bommarito A, Carissimi E, Russo L, Coppola A, Zerilli M, Rodolico V, Criscimanna A, Amato M et al. 2008 In vitro identification and characterization of CD133pos cancer stem-like cells in anaplastic thyroid carcinoma cell lines. PLoS ONE 3 e3544. (doi:10.1371/journal. pone.0003544)

Received in final form 4 March 2014

Accepted 10 March 2014

Accepted Preprint published online 17 March 2014 http://jme.endocrinology-journals.org DOI: 10.1530/JME-14-0051
() 2014 Society for Endocrinology Printed in Great Britain 